65. REIFENSTEIN, E. C., and DAVIDOFF, E. (1938), Proc. Soc. exp. Biol. N.Y., 38, 181 .

66. MICHELSEN, J., and VERLOT, M. (1939), Anesth. and Analges., $18,59$.

67. BOYD, J. (1940), Brit. med. J., 1, 729.

68. DUCKWORTH, H. C. (1940), Brit. med. J., 2, 628.

69. GUYOT, J. de V. (I94I), J. Missouri St. med. Ass., 38, 93

70. MILLER, M. M. (194I), Med. Rec., 153, I37.

7I. MILLER, M. M. (I94I), Med. Rec., 153, 8.

72. LEHOCZKY, T. (1938), Klin. Wschr., 17, 1006.

73. BRICKNER, R. M., and SIMONS, D. J. (I937), Trans. Amer. neurol. Ass., 63, 153.

74. THORNER, M. W., and YASKIN, J. C. (1937), Amer. J. med. Sci.,

75. VIETS, H. R., and SCHWAB, R. S. (1939), J. Amer. med. Ass., 113,559 .

76. (1939), J. Amer. med. Ass., 113, 2170.

77. GUTTMANN, E., and STOKES, A. B. (1939), Lancet, 2, 879.

78. BAILEY, K. C. (1943), Brit. med. J., 1, 250.

79. COBURN, D. F. (1940), J. Missouri St. med. Ass., 37, 387

8o. NICHOLS, I. C., and WARSON, S. R. (1939), New Engl. J. Med., 221, 888.

81. BRADLEY, C. (1942), Connect. St. med. J., 6, 773.

82. SARGANT,' W., and SLATER, E. (I944), "An Introduction to Physical Methods of Treatment in Psychiatry," Edinburgh: Livingstone, p. 96 .

83. BRAITHWAITE, J. V. (1944), Post-grad. med. J., 20, 350.

84. STOCKWELL, L., and SMITH, C. K. (1940), Amer. J. Dis. Child., 59, 1013.

85. MOLITCH, M., and POLIAKOFF, S. (1937), Arch. Pediat., 54, 499.

86. CARROLL, G. (1939), Nebraska St. med. J., 24, 375.

87. NATHANSON, M. H. (I937), J. Amer. med. Ass., 108, 528.

88. GOTTLIEB, J. S. (1942), Amer. J. med. Sci., 204, 553 .

89. ROBERTS, S. J., quoted by KENDIG, E. L. (1945), Sth. Med. Surg., 107, 366 .

9o. PRINZMETAL, M., and ALLES, G. A. (1940), Amer. J. med. Sci., 200, 665 .

91. HILL, J. (1936), Brit. med. J., 2, 802.

92. HILL, J. (I937), Brit. med. J., 2, I 109.

93. KEEVIL, J. J. (1938), J. roy. nav. med. Serv., 24, 219.

94. EKERFORS, H. (1938), Nord. med. Tidskr., 16, 1531.

95. ALBRECHT, F. K. (1943), Med.Clin. N. Amer., 27, 1652 (Nov.).

96. BLACKHAM, R. J. (1939), Brit. med. $J$., 2, I63.

97. HILL, I. G. W., and GUEST, A. I. (1945), Brit. med. J., 2, 6

98. SHAINE, M. S. (1938), Amer. J. med. Sci., 196, $7 \times 5$.

99. BAILEY, HAMILTON (I943), Practitioner, 150, I73.

100. TAYLOR, Z. E. (I94I), New Engl. J. Med, 224, I97.

Ioo. LAR LIN, W. J. (I94I), Pennsylvania med. J., 44, 994.

I02. HUNDLEY, J. M., KRANTZ, J. C., and HIBBITTS, J. T. (1939), Med. Clin. N. Amer., 23, 273 (March).

103. BROWN, W. B. (1942), J. Missouri med. Ass., 39, 253.

I04. JANNEY, J. C. (I945), "Medical Gynecology," Philadelphia: Saunders, pp. 70, 302 .

I05. HINDES, H. J. (1946), Industr. Med., 15, 262.

106. CAR ROLL, G. (I939), Nebraska St. med. J., 24, 375.

I07. LOMAN, J., GREENBERG, B., and MYERSON, A. (I938), New Engl.' J. Med., 219, 655.

I08. LESSES, M. F., and MYERSON, A. (1938), New Engl. J. Med., 218, II9.

Io9. COTTON, N. J. (1943), Amer. J. med. Sci., 206, 75.

IIo. CHRISMAN, R. B., and MAURY, W. (I94I), J. Tenn. St. med.

Ass., 34, 337. (1940), Endocrinology, 27, 776.
II. ERSNER,J. S. (19)

I12. ALBRECHT, F. K. (I944), Ann. intern. Med., 21, 983.

II3. ROSENTHAL, G., and SOLOMON, H. A. (1940), Endocrinology, 26, 807 .
I14. KUNSTADTER, R. H., and NECHELES, H. (1943), Amer. J med. Sci., 205, 820 .

II5. (I943), J. Amer. med. Ass., 121, 796.

II6. CUTTING, W. C. (I944), Stanford med. Bull., 2 , 172.

I17. HAWIRKO, L., and SPRAGUE, P. H. (1946), Canad. med. Ass. J., 54, 26 (Jan.).

I18. INGELFINGER, F. J. (1943), Med. Clin. N. Amer., 27, r385 (Sept.).

II9. RITVO, M. (1936), Amer. J. Roentgen., 36, 868.

I20. MYERSON, A., and RITVO, M. (1936), J. Amer. med. Ass., 107, 24. 121. SMITH, O. N., and CHAMBERLIN, G. W. (1937), Radiology, 29, 676.

I22. JENKINSON, E. L., and BROWN, W. H. (1944), Amer. J. Roentgen., $51,496$.

123. EKBOM, K.-A. (1945), Acta med. scand., supp. 158, 96.

124. SOLOMON, H. C., and YAKOVLEV, P. I. (I944), "Manual of Military Neuropsychiatry," Philadelphia: Saunders, p. 222.

125. ROBINSON, L. J. (1938), Ann. intern. Med., 12, 255.

I26. ROBINSON, L. J. (I939), Arch. Neurol. Psychiat., Chicago, 41, 290.

I27. KORNS, H. M., and RANDALL, W. L. (1937), Amer. Heart J.,

128. DAVIS, P. L., and SHUMWAY-DAVIS, M. (I937), J. Amer. med. Ass., 108, 1247.

129. BREWSTER, E. S. (1940), Ann. intern. Med., 14, 326.

r3o. POOLE, E. B., and WILKINSON, G. R. (1937), Sth. med. J., $30,1226$.

I3I. BUSCAINO, V. M., and PERO, C. (1940), Rass. internaz. clin. e terap., 21, 69I.

132. MYERSÖN, A., and THAU, W. (1937), Arch. Ophthal., Chicago, $18,78$.

I33. BEACH, S. J. (I940), Connect. St. med. J., 4, I40.

I34. WEINMAN, E. B., and FRALICK, F. B. (1940), Amer. J. Ophthal.,

I35. YUDKIIN, S. (I94I), Lancet, 1, 787 .

136. MYERSON, A. (1936), Arch. Neurol. Psychiat., Chicago, 36, 816.

I37. KORNS, H. M., and RANDALL, W. L. (r938), Ann. intern. Med. $12,253$.

138. FETTERMAN, J. L. (I945), Med. Clin. N. Amer., 29, 77 I (May).

I39, GRANT, D. N. W. (I944), " $A$ ir Force," (Official Service Journal of the U.S. Army Air Forces p. 25 (March))

140. (1943), S.G.O. Circular Letter No. 58 (Feb.), quoted by Fetterman (138).

I4I. (I942), Amer. J. Psychiat., 99, 459

I42. PELNER, L. (I944), N.Y. St. J.Med., 44, 2596.

143. ULRICH, H. (I937), New Engl. J. Med., 217, 696.

I44. ROSENBERG, P. (1942), Med. World, 60, 2 10.

145. NORMAN, J., and SHEA, J. T. (I945), New Engl. J. Med., 233, 270

146. KAUVAR, S. S., HENSCHEL, E. J., and RAVIN, A. (1943) J. Amer. med. Ass., 122, 1073

147. DAVIES, I. J. (I937), Brit. med. J., 2, 615.

148. SMITH, L. C. (1939), J. Amer. med. Ass., 113, 1022.

149. APFELBERG, B. (1938), $J$. Amer. med. Ass., 110, 575.

I50. BLOOMBERG, W. (I940), New Engl. J. Med., 222, 946.

I5r. BAKST, H. J. (1944), Nav. med. Bull., Wash., 43, I228.

I52. GORRELL, R. L. (1938), Clin. Med. and Surg., 45, 318.

I53. EHRICH, W. E., LEWY, F. H., and KRUMBHAAR, E. B. (1939), Amer. J. med. Sci., 198, 785.

154. SHORVON, H. J. (1945), Brit. med. J., 2, 285.

155. (1938), J. Amer. med. Ass., 110, 901.

156. LESSES, M. F., and MYERSON, A. (1938), J. Amer. med. Ass., 110,1507

157. GUTTMANN, E., and SARGANT, W. (1942), Brit. med. J., 1, 564. I58. SARGANT, W., and SLATER, E. (r944), "An Introduction to Physical Methods of Treatment in Psychiatry," Edinburgh: Living. stone, p. 96 .

\title{
COMMON CASES SEEN IN THE V.D. DEPARTMENT
}

\section{By Evelyn Gourlay, M.D.*}

About 80 per cent of the cases attending our V.D. Department this last year have been finally diagnosed as non-venereal, and only the remaining 20 per cent were actually infected with Syphilis, Gonorrhoea or soft sore.

This large percentage of non-venereal cases, which I think is usually much the same in the return of most women's V.D. clinics, seems to surprise many people, and they may ask why so much public money should be expended on treating such a large number of uninfected cases.

I thought it might be of interest to talk of the

* Based on a lecture given at the South London Hospital for Women on May I I, I946. problems presented by these non-venereal cases which often give us much more trouble in treatment than the straightforward case of Syphilis or Gonorrhoea. To begin with, when the patients come up often it is by no means certain whether they are or are not infected until tests have been repeated several times. During the war years we have had a great number of Services contacts where the husband or contact has written to say that he is infected and to ask the wife or friend to be examined. Some are obviously infected or show positive pathological results at once. Some appear to be quite free from infection when first seen, and later develop positive signs while being observed. 
Others have escaped infection and are finally discharged as fit, often after 3 to 4 months of observation, but must be classified as non-V.D.

Then again in some cases where we are almost certain at first sight that the condition is nonvenereal, the patient has been distracted with worry and has been the cause of much trouble to her own doctor. A definite diagnosis and treatment of such cases is important. I shall divide the cases for diagnosis into two groups:-

I. Those of the nature of vulvitis and vulval ulceration to be differentiated from Syphilis.

2. Those with a vaginal discharge to be differentiated from Gonorrhoea.

\section{Group I}

\section{Vulvitis and Vulval Ulcerations}

I feel sure in my own mind that years of war diet and deficient fats have altered the condition of the skins and mucous membranes of many of the population, and that as a result we have had more cases of non-venereal vulvitis than I have ever seen in pre-war years. This coupled with a great increase in the number who have taken risks of infection and the resulting alarm about their condition, probably explains the large numbers of such cases attending. The varieties which come up may be put under the following main headings:-

(a) A superficial surface ulceration probably associated with some local infection which has caused irritation. These may or may not be a Trichomonas vaginalis. The vulva has usually been scratched and frequently treated at home with some strong irritating disinfectant. The characteristic appearance is the staining of the outline of the ulcers with Gentian Violet after the stain has worn off the unabraded surface. There is often acute oedema of the labia, but only small septic inguinal glands are palpable.

(b) A menopausal kraurotic ulceration often seen in women in the late forties or rather older, showing some kraurotic staining and ulceration patches. The condition is usually associated with some septic condition of their less resistant vulval and vaginal mucosa.

(c) Acute Monilia vulvitis.

This condition may be associated with a typical monilia vaginitis with its characteristic thrush-like patches on the vaginal mucosa. The vulva is red, swollen and granular, often with much oedema of the labia. The whole area is acutely tender to the touch and the patient can hardly bear to walk. This condition is common in the pregnant patient, but may occur in others, and even in small girls before puberty. The diagnosis is soon established as the monilia spores are easily found in a film from the ulcerated or abraded area.

(d) $A$ simple furunculosis characterised by the infection of the hair follicles of the pubic and labial hair.

(e) Herpes of the vulva.

This may be easily recognised by the characteristic lesions and distribution, and frequently by its painful character. It may be less easy to diagnose if it takes the form of small painful punched out herpetiform ulcers of the labial mucosa, bilateral and irregular in distribution.

(f) A pre-puberty vulvitis with surface ulceration. There seems to be no obvious cause for many in of these cases, but the ulcerated surface shows in the characteristic staining with Gentian Violet of as previously described.

(g) Seborrhoeic Dermatitis.

This condition frequently involves the skin of the labia majora and mons veneris, extending out to the groins and back to the rectum. Sometimes the labia mucosa and introitus are acutely inflamed and sometimes it seems to be an external skin condition only:

(h) Less common are the last two conditions of Vincent's ulceration of the vulva or a Dodef lein infection. The Vincent's ulceration is usually diagnosed by finding the spirochaeta Vincenti and B. fusiformis in a routine film, but it must always be remembered that a Vincent's infection may be super-imposed on secondary syphilitic ulceration.

The Doderlein infection is not common, and is seen in small girls, where the Doderlein bacillus of the healthy adult vagina has become pathogenic and caused rounded punched out ulcers with a greyish base and an acutely red area round the rim of the ulcer.

A rapid method of differential diagnosis as to whether any of these conditions are syphilitic or not $₹$ is by palpation of the inguinal glands. In primary 윽 and secondary syphilitic ulceration the inguinal $D$ glands are large, elastic and painless, and frequently seem enlarged out of all proportion to the size of $\vec{N}$ the vulval lesion. In the absence of such glands it o is always doubtful if any vulval lesion is syphilitic. $N$ This assessment of the case must be checked by $N_{\omega}$ taking smears for spirochaetes from any suspicious 0 ulcer and repeated blood for Wassermann reaction. 0

I always feel that the more dramatic the history $\frac{D}{\Phi}$ and description of the condition given by the $\stackrel{\oplus}{\rightarrow}$ patient the less likely is it to prove to be venereal. 0 The chancre of Syphilis often passes unnoticed by the patient and it is amazing how little they seem 
to have been troubled by appalling condylomata. Intense vulval soreness and painful inguinal adenitis usually contra-indicates a diagnosis of Syphilis unless there is some secondary infection, or the ulceration has been treated with some irritating disinfectant.

\section{Group II}

Now for the second group of cases, the vaginal discharges to be differentiated from Gonorrhoea; 'the pouring discharge with offensive smell, causing acute vulval soreness and irritation rarely turns out to be gonococcal. The profuse offensive discharge is most likely due to:-

(a) Trichomonas Vaginitis.

This causes a characteristic frothy yellow discharge with an acute granular vaginitis. The cervix is red all over but usually shows no endocervicitis as is the case with gonococcal infection. If the granular inflamed vagina of a Trichomonas vaginitis is painted out with Hydrogen peroxide, the raw granular prominences of the rugae are picked out on white patches. This is a very characteristic appearance diagnostic of the infection.

(b) The Monilia infection.

This also causes an acute vaginitis, particularly in pregnant women. The vagina and vulva are acutely inflamed with curdy white patches of thrush on the vaginal walls right down to the introitus.

(c) B. Coli and septic infections.

These infections are clinically similar to the Trichomonas vaginitis and may sometimes be responsible for involvement of the Bartholin glands.

(d) Vulval and vaginal warts.

These warts which should be described noncommittally before tests as "vulval warts" are in themselves simply the outcome of the irritation of a chronic discharge over the mucous membranes of the vagina and introitus or the skin of the labia, perineum and anus.

The two essentials for their production is the presence of irritation with the type of skin and mucosa which becomes granular and warty in response. The patient who has vulval warts is not often Gc. positive on the cervical film. Often we know that they have been cases of Gonorrhoea who attended originally for treatment and then lapsed, only returning when alarmed by the warts. These cases are usually negative in their films when the warts have appeared. Most frequently I do not think that they have had Gonorrhoea at all, but have neglected a chronic septic or Trichomonas vaginitis which has caused the warts by irritation.

The blonde and red head seem to have particularly susceptible skins and in all patients the warts proliferate enormously with pregnancy. The small clumps of warts round the anus in the absence of any rectal discharge are, I think, due to the trickling back over the perineum of a scanty vaginal discharge which collects in a pool over the anus causing warty proliferation of the skin. Many of the bad wart cases can be treated as out-patients, but in pregnancy the condition may be so bad that hospitalisation is essential.

To finish I am giving the outlines of the few simple local treatments which we use for these conditions:-

\section{Trichomonas Vaginitis}

I. Gentian Violet or Bonney's Blue to cervix. Stovarsol vaginal tablets and tampon.

2. Negatol loo per cent to cervix and vagina. Negatol pessary Io per cent.

This must be preceded by a swabbing out with bicarbonate of soda to remove all mucus.

\section{Vulval and Vaginal Warts}

Treat any discharge by one of above methods leaving the vagina as dry as possible. If necessary fill the vagina up with powder to dry. Podophyllin Resin (25 per cent in Castor oil) to warts, dust warts and vulva well with powder. A good drying powder is:-

$$
\begin{array}{ll}
\text { Bismuth Subgallate } & \text { I part. } \\
\text { Zinc. Oxide } & 2 \text { parts. } \\
\text { Mag. Carb. Levis } & 2 \text { parts. }
\end{array}
$$

Cremor Zinci should be given to the patient for application at home as the surface is very sore when the warts fall off.

\section{Non-Venereal Vulvitis}

\section{Local}

The vulva must be protected from water. Gentian Violet is I per cent applied and Cremor Zinci continuously. As little bathing as possible.

Sulphathiazole Cream 5 per cent to any septic ulceration. If really bad, confinement to bed is essential.

\section{Oral}

Radiostoleum or Adexolin.

Nicotinic Acid 50 mgs.t.d.s.

Riboflavin. I mg. t.d.s.

In menopausal cases-Hexoestrol I mg. t.d.s. 